\title{
Diet quality and its implications on the cardio-metabolic, physical and general health of older men: the Concord Health and Ageing in Men Project (CHAMP)
}

\author{
Rosilene V. Ribeiro ${ }^{1,2 *}$, Vasant Hirani ${ }^{1,2}$, Alistair M. Senior ${ }^{3}$, Alison K. Gosby ${ }^{1,4}$, Robert G. Cumming ${ }^{2,5,6}$, \\ Fiona M. Blyth ${ }^{2}$, Vasi Naganathan ${ }^{2}$, Louise M. Waite ${ }^{2}$, David J. Handelsman ${ }^{7}$, Hal Kendig ${ }^{6,8}$, \\ Markus J. Seibel ${ }^{7}$, Stephen J. Simpson ${ }^{1}$, Fiona Stanaway ${ }^{5}$, Margaret Allman-Farinelli ${ }^{1}$ and \\ David G. Le Couteur ${ }^{1,2,7}$ \\ ${ }^{1}$ School of Life and Environmental Sciences, Charles Perkins Centre, University of Sydney, Sydney, NSW, 2006, Australia \\ ${ }^{2}$ Centre for Education and Research on Ageing and Ageing and Alzheimers Institute, Concord Hospital, University of Sydney, \\ NSW, 2139, Australia \\ ${ }^{3}$ School of Mathematics and Statistics, University of Sydney, NSW, 2006, Australia \\ ${ }^{4}$ Boden Institute of Obesity, Nutrition, Exercise and Eating Disorders, Charles Perkins Centre, University of Sydney, NSW, 2006, \\ Australia \\ ${ }^{5}$ School of Public Health, University of Sydney, NSW, 2006, Australia \\ ${ }^{6}$ Australian Research Council - Centre of Excellence in Population Ageing Research (ARC-CEPAR), Kensington, NSW, 2033, \\ Australia \\ ${ }^{7}$ ANZAC (Australian and New Zealand Army Corps) Research Institute, University of Sydney, Concord Hospital, Concord, \\ NSW, 2139, Australia \\ ${ }^{8}$ Centre for Research on Ageing, Health, and Wellbeing, Research School of Population Health (RSPH), Australian National \\ University, Acton, ACT, 2601, Australia
}

(Submitted 26 January 2017 - Final revision received 25 May 2017 - Accepted 16 June 2017)

\section{Abstract}

The revised Dietary Guideline Index (DGI-2013) scores individuals' diets according to their compliance with the Australian Dietary Guideline (ADG). This cross-sectional study assesses the diet quality of 794 community-dwelling men aged 74 years and older, living in Sydney, Australia participating in the Concord Health and Ageing in Men Project; it also examines sociodemographic and lifestyle factors associated with DGI-2013 scores; it studies associations between DGI-2103 scores and the following measures: homoeostasis model assessment - insulin resistance, LDLcholesterol, HDL-cholesterol, TAG, blood pressure, waist:hip ratio, BMI, number of co-morbidities and medications and frailty status while also accounting for the effect of ethnicity in these relationships. Median DGI-2013 score was $93 \cdot 7$ (54.4, 121.2); most individuals failed to meet recommendations for vegetables, dairy products and alternatives, added sugar, unsaturated fat and SFA, fluid and discretionary foods. Lower education, income, physical activity levels and smoking were associated with low scores. After adjustments for confounders, high DGI-2013 scores were associated with lower HDL-cholesterol, lower waist:hip ratios and lower probability of being frail. Proxies of good health (fewer comorbidities and medications) were not associated with better compliance to the ADG. However, in participants with a Mediterranean background, low DGI-2013 scores were not generally associated with poorer health. Older men demonstrated poor diet quality as assessed by the DGI-2013, and the association between dietary guidelines and health measures and indices may be influenced by ethnic background.

\section{Key words: Ageing: Men: Australia: Diet quality}

Old age is a major risk factor for disease and poor health and the number of older people is increasing, leading to a growing recognition of the need to develop strategies to reduce the health burden associated with aging ${ }^{(1)}$. Nutrition is one of the most important and modifiable factors affecting health in older age ${ }^{(2)}$. Using crosssectional baseline data, the Melbourne Longitudinal Study on Healthy Aging identified nutrition at baseline as an independent predictor of independence in daily living, good self-rated health and psychological wellbeing (i.e. 'ageing well') in older communitydwelling individuals ${ }^{(3)}$. Ethnicity has also been identified as a predictor of successful ageing ${ }^{(4,5)}$. For example, people who consume diets associated with particular cultures, such as the Mediterranean and Okinawan diets, appear to have improved health outcomes and longevity ${ }^{(6,7)}$. On the negative side, older individuals tend to have suboptimal diets ${ }^{(8-11)}$. This particularly applies to older men who are at an even higher risk of nutritional inadequacies than

Abbreviations: ADG, Australian Dietary Guideline; CHAMP, Concord Health and Ageing in Men Project; COB, Country of birth; DGI, Dietary Guideline Index; DHQ, diet histories questionnaire; HOMA-IR, homoeostasis model assessment - insulin resistance.

* Corresponding author: Dr R. V. Ribeiro, email rosie.waern@sydney.edu.au 
women secondary to limited involvement in the planning and preparation of meals ${ }^{(12)}$ and nutritional knowledge ${ }^{(13)}$. Therefore, it is important that studies examining the relationship between diet and health take age, sex and ethnicity into consideration.

There are many approaches to investigating the relationship between dietary intake and health. Traditionally, 'single nutrient' or 'one-variable-at-a-time, ${ }^{\text {,(14) }}$ approaches have been used to explore associations between individual nutrients and health outcomes and this has been very effective for identifying the effects of nutritional deficiencies ${ }^{(15,16)}$. However, with increasing rates of diet-related obesity and cardio-metabolic diseases ${ }^{(16)}$, and a growing recognition of the complexity of diets and interactions between nutrients, there has been a shift towards exploring the relationship between health and broader classifications of dietary composition. Dietary patterns analysis has emerged as one such method to investigate the association between dietary intake and risk of chronic diseases ${ }^{(15)}$. This type of method focuses on foods and their intake rather than specific nutrients.

The 'dietary index' is a type of dietary pattern analysis in which individuals' diets are scored according to how well they comply with established dietary guidelines ${ }^{(17)}$. The revised Australian Dietary Guideline Index (DGI-2013) ${ }^{(18)}$ is a food-based dietary index developed to investigate the compliance of adults to the Australian Dietary Guidelines (ADG) ${ }^{(17)}$ (Table 1). The ADG are based on evidence related to the prevention of diet-related conditions and chronic diseases and the Australian National Health and Medical Research Council nutrient reference values ${ }^{(17)}$.

Using the dietary index approach we investigated the association between food intake and health measures and indices in older men using data from the Concord Health and Ageing in Men Project (CHAMP). This cohort study was established to investigate geriatric syndromes of older men and the relationship between nutrition and health $^{(19)}$. One-quarter of the CHAMP participants have Italian or Greek (Mediterranean) backgrounds, which has provided an opportunity to investigate whether the relationship between the DGI-2013 and health is influenced by ethnicity. Therefore, the aims of this study were to evaluate diet quality of older men using the DGI-2013, to discover sociodemographic and lifestyle factors associated with it, to investigate the associations between diet quality and some health measures and indices common in older age while accounting for the effect of ethnicity on these relationships.

\section{Methods}

\section{Participants}

The original selection of CHAMP subjects has been described in detail elsewhere ${ }^{(19)}$. In brief, 1705 men aged 70 years and over

Table 1. Components and scoring methods of the revised Dietary Guideline Index (DGI-2013)

\begin{tabular}{|c|c|c|c|c|}
\hline Dietary guidelines & Indicator and description & $\begin{array}{c}\text { Criteria for } \\
\text { maximum score* }\end{array}$ & $\begin{array}{l}\text { Criteria for } \\
\text { minimum score }\end{array}$ & $\begin{array}{l}\text { Maximum } \\
\text { score }\end{array}$ \\
\hline \multicolumn{5}{|l|}{ Guidelines for adequate intake } \\
\hline 1. Enjoy a variety of nutritious foods $t$ & Number of food items consumed per day & $\geq 19$ & $<19$ & 10 \\
\hline 2. Vegetables and legumes/beans & Total vegetable intake: servings per day & $\geq 5$ & 0 & 10 \\
\hline 3. Fruit & Total fruit intake: servings per day & $\geq 2$ & 0 & 10 \\
\hline \multirow{2}{*}{$\begin{array}{l}\text { 4. Grain (cereal) foods, mostly wholegrain } \\
\text { and/or high cereal fibre varieties }\end{array}$} & a. Total grains intake: servings per day & $\geq 4.5$ & 0 & 5 \\
\hline & $\begin{array}{l}\text { b. Chooses mostly wholegrain or high fibre } \\
\text { cereals }\end{array}$ & $\geq 50 \%$ & 0 & 5 \\
\hline $\begin{array}{l}\text { 5. Meats and poultry, fish, eggs, tofu, nuts and } \\
\text { seeds and legumes/beans }\end{array}$ & $\begin{array}{l}\text { Total meat and alternatives intake: servings } \\
\text { per day }\end{array}$ & $\geq 2 \cdot 5$ & 0 & 10 \\
\hline 6. Milk, yogurt, cheese & $\begin{array}{l}\text { Total dairy products and alternatives intake: } \\
\text { servings per day }\end{array}$ & $\geq 3 \cdot 5$ & 0 & 10 \\
\hline \multirow{2}{*}{ 7. Drink plenty of water } & a. Total beverage intakeł: litres per day & $\geq 2 \cdot 6$ & 0 & 5 \\
\hline & $\begin{array}{l}\text { b. Water: proportion of water to total } \\
\text { beverage intake per day }\end{array}$ & $\geq 50$ & 0 & 5 \\
\hline \multicolumn{5}{|l|}{ Guidelines to limit or moderate intake } \\
\hline $\begin{array}{l}\text { 8. Limit intake of foods containing SFA, added } \\
\text { sugars and alcohol }\end{array}$ & Limit discretionary foods & $\leq 3$ & $>3$ & 10 \\
\hline $\begin{array}{l}\text { 9. Small allowance of unsaturated oils, fats or } \\
\text { spreads }\end{array}$ & $\begin{array}{l}\text { Unsaturated spreads and oils: servings } \\
\text { per day }\end{array}$ & $\leq 2$ & $>2$ & 10 \\
\hline 10. Limit intake of foods high in SFA & Limit SFA intake§ & $\leq 10 \% \mathrm{E}$ & $>10 \% \mathrm{E}$ & 10 \\
\hline $\begin{array}{l}\text { 11. Limit intake of foods and drinks containing } \\
\text { added sugars }\end{array}$ & Limit extra sugar: servings per day\|l & $\leq 1.5$ & $>1.5$ & 10 \\
\hline $\begin{array}{l}\text { 12. Limit intake of foods and drinks containing } \\
\text { added salt }\end{array}$ & Limit $\mathrm{Na}$ intake & $460-2300 \mathrm{mg}$ & $<460$ or $>2300 \mathrm{mg}$ & 10 \\
\hline 13. If you choose to drink alcohol, limit intake & Limit alcohol: servings per day & $\leq 2$ & $>2$ & 10 \\
\hline
\end{tabular}

$\%$ E, percentage contribution to total energy.

* Criteria for maximum score has been derived from Australian Dietary Guidelines (1) according to age (70+) and sex (male) unless otherwise noted and total possible score $=130$.

$\dagger$ Food variety scores were calculated based on the number of different food items consumed in a day; food item was only considered if it belonged to a core food group (grains, fruit, vegetable, protein foods and dairy products); if participant was to consume a different food item to meet their requirements of each food group, he would consume a minimum of nineteen different food items (rounded as one cannot consume half of a new food item.

‡ Fluid intake included water and water present in milk, fruit juice, tea and coffee.

$\S$ Amount of SFA as a percentage of total energy.

॥ Since added sugar intake is not recommended there are no cut-off values for the number of recommended servings, instead half of the maximum discretionary food cut-off were used consistent with the original DGI.

II $\mathrm{Na}$ intake derived from salt added before or after cooking, packaged food items and salt naturally present in food. 
living in the suburbs of Burwood, Canada Bay and Strathfield in Sydney, Australia who were on the electoral roll enrolled in CHAMP at baseline (2005-2007). Participants have been followed up since $2005^{(19)}$, and in 2012 during the 5-year follow-up (third follow-up wave), the nutritional data were collected from 794 participants who completed a diet history questionnaire ${ }^{(20)}$.

All participants gave written informed consent. The study was approved by the Sydney South West Area Health Service Human Research Ethics Committee, Concord Repatriation General Hospital, Sydney, Australia.

\section{Dietary intake}

The dietary assessment method used in CHAMP has been described elsewhere ${ }^{(20,21)}$. In brief, typical dietary intake was assessed using a diet histories questionnaire (DHQ) and covered usual intake over the past 3 months ${ }^{(22)}$ A research dietitian conducted and recorded all diet histories in the participant's residence with the process averaging $45 \mathrm{~min}$ for completion. The validity of DHQ was established by comparison to a 4-d weighed food record collected in a subgroup of fifty-six CHAMP men and results published previously ${ }^{(21)}$.

\section{Data handling and database conversion}

Participants' daily dietary intakes were initially analysed using FoodWorks 7 Professional for Windows (2012; Xyris Software (Australia) Pty Ltd), which uses the Australian food, supplement and nutrient database 2007 (AUSNUT 2007). The national database has recently been updated (AUSNUT2001-13) therefore we have used the matching file ${ }^{(23)}$ to update all foods and recipes information from reported intake in the CHAMP study; this database also converts participants' number of serves of each food group. Branded products were matched to AUSNUT 2007 food name using AUSNUT 2007 Brand Match File ${ }^{(24)}$, then AUSNUT 2007 food name was matched to AUSNUT 2011-13 using matching file ${ }^{(23)}$. Foods that were not completely matched via AUSNUT 2007 to 2011-13 matching file were manually matched by an experienced research dietitian (R. V. R.).

\section{Revised Dietary Guideline Index}

The original Australian DGI ${ }^{(25)}$ is a food-based dietary index developed to investigate the compliance of adults to the Dietary Guidelines for Australian Adults ${ }^{(26)}$. Thorpe et al. ${ }^{(18)}$ revised the original DGI after the release of the new ADG containing changes in terminology and recommendations according to age and sex as well as a new component related to unsaturated fats.

Details of DGI-2013 has been provided elsewhere ${ }^{(18)}$, in brief, the DGI-2013 is comprised of thirteen components each scored out of 10 (overall possible maximum score $=130$ ), with 0 indicating low compliance to ADG and 10 better compliance, and therefore, higher diet quality. DGI-2013 is divided into categories of adequate intake (intake encouraged) and moderate intake (restrict intake recommended). Cut-offs for maximum and minimum scores are presented in Table 1 which was adapted from Thorpe et al. ${ }^{(18)}$ publication.

The DGI (original and revised) were developed using data obtained through a 111-item FFQ. However, in the present study we have used DHQ to assess food intake that means there are no limitations on the number and quantities of food and beverages reported as is the case with FFQ. Therefore because of the nature of the data obtained - more quantitative than qualitative information - the following adaptations of DGI criteria were made:

(1) Added salt intake was not assessed in this study; therefore overall dietary $\mathrm{Na}$ intake was used to measure compliance with ADG. Individuals who consumed between 460 and $2300 \mathrm{mg}$ (lower cut point of adequate intake to upper level of intake $)^{(27)}$ of $\mathrm{Na}$ a day received the maximum score.

(2) For the guideline about limiting intake of foods high in SFA, the percentage of total energy derived from SFA was used as information on fat trimming and type of milk was not systematically collected in the present study.

(3) Variety of food intake was measured based on the number of different foods participants consumed a day. For this calculation, only core food groups were taken into consideration because they are the basis of a balanced diet containing essential macro and micronutrients ${ }^{(28)}$. A participant received the maximum score for food variety if they consumed at least nineteen different foods from core food groups.

(4) Total fluid intake was calculated by summing participant's intake of water (including water present in coffee and tea), milk and fruit juice ${ }^{(17)}$.

(5) Solid fat equivalents was calculated by summing fats naturally occurring in meat, poultry, eggs, dairy products, fully or partially hydrogenated oils, shortening, palm oil and coconut oil.

(6) Number of serves of discretionary foods was determined by summing the number of serves of added sugar ( 1 teaspoon $(4 \cdot 2 \mathrm{~g})=1$ serve $)$, solid fat equivalents $(1$ teaspoon $(4 \cdot 8 \mathrm{~g})=1$ serve) and alcoholic drinks ( 1 standard drink $=1$ serve).

\section{Sociodemographic and lifestyle factors}

Data on sociodemographic and economic factors, smoking status and physical activity were obtained through a selfcompleted questionnaire. Country of birth (COB) was grouped into three categories: (1) Australia and New Zealand; (2) Italy and Greece; and (3) other (total of thirty-eight countries). Income source was used as a proxy for personal income, assuming that age pensioners had the lowest income (age pensioners are provided with a modest pension if they are unable to support themselves) compared with those with other incomes, that is, repatriation pension, veteran's pension, superannuation or other private income, own business/farm/ partnership, wage or salary, other or any income source combination $^{(4)}$. Information on who is responsible for grocery shopping and cooking was obtained during the diet history interview and the data were dichotomised as self or other/ assisted. Self-rated health data were obtained and dichotomised into excellent/good $v$. fair/poor/very poor.

\section{Health measures and indices of interest}

Number of co-morbidities and medications. Data on medical conditions were obtained from a self-reported questionnaire in 
which participants reported to be professionally diagnosed with any of the following diseases: diabetes, thyroid problems, osteoporosis, Paget's disease of bone, stroke, Parkinsons disease, kidney stones, dementia, depression, epilepsy, hypertension, myocardial infarction, angina, heart failure, peripheral vascular disease, chronic obstructive pulmonary disease, liver disease, chronic kidney disease, arthritis and cancer (excluding non-melanotic skin cancer and benign tumours such as bowel polyps and meningioma). Multi-morbidity was defined as having two or more of these conditions ${ }^{(29)}$. Participants were asked to bring prescription and non-prescription medications used daily or almost daily to their 5-year follow-up clinic appointment. Polypharmacy was defined as the use of five or more regular prescription medicines ${ }^{(30)}$.

Insulin sensitivity, lipidaemia and blood pressure. Fasting blood was collected from 663 (84\%) participants to measure circulating levels of glucose, insulin, TAG, LDL-cholesterol and HDL-cholesterol. Each of these measures was performed at the Diagnostic Pathology Unit of Concord RG Hospital, which is a National Australian Testing Authority accredited pathology service, using a MODULAR Analytics system (Roche Diagnostics). Levels of cholesterol and HDL-cholesterol were measured on a Roche Cobas 8000 analyser (Roche Diagnostics International Ltd) using a standard automated enzymatic methodology. Fasting blood samples for glucose measurement were put into fluorideoxalate (anticoagulant) tubes. Plasma glucose was measured using the Hexokinase method. homoeostasis model assessment insulin resistance (HOMA-IR) was calculated using HOMA calculator version 2.2.3 ( ${ }^{\circ}$ Diabetes Trials Unit, University of Oxford). The remaining 128 (16\%) participants were not fasted at the time of blood collection and so the results for these participants have not been included in the current analysis. Blood pressure was measured by trained staff according to a standardised protocol using a sphygmomanometer as previously described $^{(31)}$. Participants with systolic blood pressure $\geq 140 \mathrm{mmHg}$ and diastolic $\geq 90 \mathrm{mmHg}$ were categorised as hypertensive, those with systolic blood pressure $120-139 \mathrm{mmHg}$ and diastolic $80-89 \mathrm{mmHg}$ were categorised as normal-high blood pressure and those with systolic blood pressure $<120 \mathrm{mmHg}$ and diastolic $<80$ $\mathrm{mmHg}$ were categorised as normal blood pressure ${ }^{(32)}$.

Anthropometry. Height and weight were measured according to a standardised protocol ${ }^{(33)}$ and BMI was calculated as $\mathrm{kg} / \mathrm{m}^{2}$. BMI was categorised as underweight $\left(<22 \mathrm{~kg} / \mathrm{m}^{2}\right)$, normal $\left(22-30 \mathrm{~kg} / \mathrm{m}^{2}\right)$ and overweight/obese $\left(>30 \mathrm{~kg} / \mathrm{m}^{2}\right)$ in accordance with recent studies in older individuals (65 years and over) showing an increased risk of mortality in the lowest and highest cut-offs ${ }^{(34-39)}$. Waist and hip circumferences were measured following a standardized protocol as recommended by the World Health Organization $^{(40)}$. Values above 0.9 (for men) indicate an increased health risk because of the abdominal obesity ${ }^{(40)}$. Activity level was determined through the Physical Activity Scale for the Elderly (PASE). The PASE questionnaire includes twelve types of occupational, household and leisure related activities from previous 7-d period; scoring is calculated from weights (e.g. intensity and duration) and frequency values for each type of activity $^{(41)}$
Frailty status. Frailty scores were determined using the five frailty components used in the Cardiovascular Health Study $(\mathrm{CHS})^{(42)}$. Weakness and slowness components were determined using the same criteria and the same cut-off points as in the $\mathrm{CHS}^{(42)}$. Weight loss, exhaustion, and low activity criteria were adapted in the CHAMP study, as the exact measurements used in the CHS were not available. Weight loss was defined as current weight lower by $15 \%$ or more than self-reported heaviest weight (or than weight at 25 years old, if missing data on heaviest weight); participants were asked 'How much of the time during the past 4 weeks did you have a lot of energy?' ${ }^{\text {(43), }}$, and classified as exhausted if their response was 'a little' or 'none of the time'; low activity was defined as being in the lowest quintile on the PASE (cutoff score $<73)^{(41)}$. Participants were classified as follows: frail (score $\geq 3$ ), pre-frail (score 1-2) and robust $(\text { score }=0)^{(42)}$.

\section{Statistical analysis}

Data on number of serves of each food group, individual DGI component scores and total DGI scores were checked for normality using graphical and statistical methods (Shapiro-Wilk test) and were found to have skewed distribution, hence, medians and ranges (minimum to maximum) were calculated. Percentages of individuals meeting each component of DGI were also calculated.

To discover factors associated with diet quality (as per DGI-2013), we used a multi-model inference procedure based on information theory ${ }^{(44)}$. We first implemented a global linear model (LM) using the 'glm' function in the base package within the statistical programming environment $\mathrm{R}$ version 3.3.0 for windows ${ }^{(45)}$, which contained DGI score as the response and all potential predictors of diet quality (age, marital status, level of education, income source, cooking responsibility, grocery shopping responsibility, smoking status, physical activity level, BMI and its quadratic effect) fitted additively. BMI was considered as both a predictor of DGI and an outcome of poor compliance to DGI. COB is a well-known factor associated with dietary patterns ${ }^{(46,47)}$ and was explored in detail separately but not included in the model for the following reasons: (1) 'other' category contained forty-eight countries including England/UK, China, Croatia, Hungary and Malta, for example, making this a very heterogeneous group with not many similarity in terms of dietary patterns, and (2) excluding participants from 'other' COB was an option we avoided as that would significantly reduce our sample and the power of our analyses. The model was standardised to the $Z$ scale using the 'standardise' function in the $\mathrm{arm}$ package ${ }^{(48)}$. A set of candidate models was created using the 'dredge' function in the MuMIn package ${ }^{(49)}$. Models were then ranked based on Akaike information criterion with correction for small sample size (AICc). Rather than restrict our inference to that based on a single 'best-fitting' model, which may be subject to model-selection uncertainty and modelselection bias, we used multi-model inference ${ }^{(50)}$. From the set of candidate models, a top model set comprising those models with an AICc within two of the top model (that with the lowest AICc) were obtained. Model-averaged coefficients were then obtained using the 'model.avg' function in MuMIn. For each 
coefficient we also report relative importance, adjusted SE, $95 \%$ $\mathrm{CI}(1.96 \times \mathrm{sE})^{(51)}$, and the coefficient estimates with shrinkage. $R^{2}$ for global model was calculated using the equation 10 in Nakagawa \& Schielzeth ${ }^{(52)}$.

Chi-square and Mann-Whitney $U$ test were used to compare DGI-2013 scores, food intake and health measures of Italian and Greek-born men v. Australian and New Zealand-born participants.

We examined whether DGI-2013 scores predicted health measures and indices by independently fitting each health measure as the response in a model with DGI score as the predictor. We explored models that were fitted both with and without socioeconomic factors that were associated with DGI-2013 (based on model averaging) and that differed between ethnic groups (Australia/New Zealand $v$. Italy/ Greece). We used LM for continuous health measures and indices (HOMA-IR, LDL-cholesterol, HDL-cholesterol, TAG, waist:hip ratio and BMI) and quasi-poisson (log-link) generalised linear models (GLM) for all health measures and indices quantified as integers (number of co-morbidities and medications), implemented with the 'glm' function in the base package. For measures and indices expressed in categories (hypertension and frailty status), we used multinomial (logit-link) GLM implemented with the 'multinom' function in the nnet package $^{(53)}$. For all multinomial measures and indices, the healthy status (normal blood pressure and robust) was fitted as the multinomial denominator. These analyses were performed in the whole sample. However, we also explored a subset of the data including only Australian/New Zealander and Italian/ Greek-born participants. For this subset of the data we fitted models with interactions (i.e. effect-modifier) between COB and DGI score to explore whether DGI differentially predicted health as a function of ethnic background. Evidence against the null hypotheses was considered statistically significant if the resulting $P$ values were $<0 \cdot 05$.

\section{Results}

\section{Participants' characteristics, food intake and Dietary} Guideline Index scores

Participants' characteristics are presented in Table 2. The median age was 80 years (74-98) and median BMI was 27.5 $\left(15 \cdot 2-43 \mathrm{~kg} / \mathrm{m}^{2}\right)$. The majority of participants were Australian or New Zealand-born ( $n$ 427), married and relied exclusively on the age pension as income source. Italian and Greek-born participants ( $n$ 188) were significantly less educated, more likely to live exclusively on the age pension and be married. Australian and New Zealand-born men were less likely to be smokers or former smokers, had a higher HDL-cholesterol and were more likely to rate their health as excellent/good. Overall, health measures and indices were similar in both groups (Table 2).

Participants' median food intake, DGI-2013 scores and proportion meeting guidelines are presented in Table 3 . The average DGI-2013 score was 93.7 (54.4-121.2) with the majority of participants meeting the minimum guidelines for grains/cereals, meat and alternatives, water, alcohol and salt intake. Median dairy products and vegetable intakes were considerably below minimum guidelines. Only $1 \%$ of the population consumed more than the recommended 2.6 litre of fluid per day. The majority of the population failed to consume enough fluid and over-consumed unsaturated fat and discretionary foods.

\section{Factors associated with Dietary Guideline Index compliance}

The top model set for predictors of DGI score, and associated AICc values is given in the online Supplementary Table S1. Model-averaged coefficients from these models are presented in the online Supplementary Table S2. Higher level of education, income and physical activity were associated with higher DGI scores, whereas being a smoker was associated with lower DGI scores.

\section{Dietary Guideline Index-2013 and health measures and indices}

Table 4 shows the results of analyses investigating the association between health measures and indices and DGI-2013 before and after adjustment for factors education and income. After adjustments, high DGI scores were associated with lower HDL-cholesterol, lower waist:hip ratios and lower probability of being frail. Proxies of good health such as fewer co-morbidities and medications were not associated with better compliance to the ADG.

\section{The influence of ethnicity on Dietary Guideline Index and} health measures and indices

The DGI-2013 scores of men born in Italy and Greece was significantly lower than those born in Australia and New Zealand (Table 3). Total energy intakes were similar between the two groups of men; however, Italian and Greek-born men consumed less total energy from protein and carbohydrate but more from fat. Italian and Greek-born men had higher intake of total and MUFA fat intake, red and orange vegetables, legumes (both as vegetables and as meat alternative), refined cereals, alcohol, oil equivalents, legume protein and fresh vegetables (tomatoes, dark green, red and orange vegetables) and lower intakes of SFA, starchy vegetables, wholegrain cereals, nuts, dairy products and discretionary foods including added sugar, SFA and salt (Table 3).

In the subset analysis (Australian/New Zealander and Italian/ Greek-born participants only) investigating effect of COB on the relationship between DGI and health measures and indices, we found significant interaction between COB and DGI scores for probability of being classified as frail $(P=0 \cdot 01)$, HOMA-IR $(P=0.005)$, number of co-morbidities $(P=0.039)$ and medications $(P=0.005)$ (Table 5$)$. For those born in Australia and New Zealand, higher DGI-2013 scores were associated with lower HOMA-IR, number of co-morbidities, medications and lower probability of being classified as frail whereas for Italian and Greek-born men, increasing DGI scores had the opposite effect (Table 5, Fig. 1). 
Table 2. Concord Health and Ageing in Men Project participants' characteristics

(Percentages and numbers; medians and ranges)

\begin{tabular}{|c|c|c|c|c|c|c|c|}
\hline \multirow[b]{2}{*}{ Characteristic } & \multicolumn{2}{|c|}{ Overall $(n 794)^{\star}$} & \multicolumn{2}{|c|}{ Born in Australia/New Zealand ( $n$ 427) } & \multicolumn{2}{|c|}{ Born in Italy/Greece ( $n$ 188) } & \multirow[b]{2}{*}{$P$} \\
\hline & $\%$ & $n$ & $\%$ & $n$ & $\%$ & $n$ & \\
\hline \multicolumn{8}{|l|}{ Sociodemographic } \\
\hline Age (years) (n 794) & \multirow{3}{*}{\multicolumn{2}{|c|}{$\begin{array}{c}80 \\
74-98\end{array}$}} & & & & & 0.14 \\
\hline Median & & & \multirow{2}{*}{\multicolumn{2}{|c|}{$\begin{array}{c}81 \\
74-98\end{array}$}} & \multirow{2}{*}{\multicolumn{2}{|c|}{$\begin{array}{c}80 \\
75-93\end{array}$}} & \\
\hline Range & & & & & & & \\
\hline \multicolumn{7}{|l|}{ Post-school qualifications ( $n$ 791) } & $<0.001$ \\
\hline Bachelor degree or higher & 15 & 120 & 20 & 84 & 5 & 1 & \\
\hline Trade/apprenticeship & 24 & 187 & 25 & 108 & 16 & 30 & \\
\hline Certificate/diploma & 20 & 56 & 25 & 105 & 9 & 16 & \\
\hline High school and below & 41 & 328 & 30 & 130 & 75 & 139 & \\
\hline \multicolumn{7}{|l|}{ Income source $(n 791) \dagger$} & $<0.001$ \\
\hline Otherf & 40 & 315 & 25 & 105 & 63 & 118 & \\
\hline Age pension only & 60 & 479 & 75 & 322 & 37 & 69 & \\
\hline \multicolumn{7}{|l|}{ Marital status ( $n 794)$} & $<0.001$ \\
\hline Married/de facto & 75 & 597 & 70 & 299 & 86 & 161 & \\
\hline Divorced/separated/widowed/never married & 25 & 194 & 30 & 128 & 14 & 26 & \\
\hline \multicolumn{8}{|l|}{ Country of birth ( $n 794)$} \\
\hline Australia/New Zealand & 54 & 427 & & & & & \\
\hline Italy/Greece & 24 & 188 & & & & & \\
\hline Other§ & 22 & 179 & & & & & \\
\hline Lifestyle & & & & & & & \\
\hline Smoking status ( $n$ 776) & & & & & & & $<0.001$ \\
\hline Never smoked & 40 & 313 & 48 & 202 & 24 & 44 & \\
\hline Former smokers & 56 & 434 & 50 & 209 & 69 & 122 & \\
\hline Current smokers & 4 & 29 & 2 & 10 & 7 & 13 & \\
\hline PASE $(n 794)$ & & & & & & & \\
\hline Median & & & & & & & \\
\hline Range & & $7 \cdot 4$ & & & & & \\
\hline Body composition & & & & & & & \\
\hline BMI $\left(\mathrm{kg} / \mathrm{m}^{2}\right)(n 745)$ & & & & & & & 0.59 \\
\hline Normal weight (22-30) & 41 & 304 & 43 & 202 & 46 & 85 & \\
\hline Underweight $(<22)$ & 7 & 46 & 48 & 182 & 48 & 89 & \\
\hline Overweight/obese $(>30)$ & 60 & 444 & 9 & 37 & 6 & 12 & \\
\hline Median & & & & & & & \\
\hline Range & & 43.0 & & & & & \\
\hline Waist:hip ratio ( $n 747)$ & & & & & & & 0.002 \\
\hline$>0.9$ & 96 & 716 & 90 & 378 & 98 & 180 & \\
\hline Cardio-metabolic & & & & & & & \\
\hline HOMA-IR (n 655) & & & & & & & 0.12 \\
\hline Median & & & & & & & \\
\hline Range & & $13 \cdot 3$ & & & & & \\
\hline Hypertension (n 774)॥ & & & & & & & 0.95 \\
\hline Yes & 71 & 550 & 70 & 293 & 69 & 129 & \\
\hline HDL-cholesterol ( $n$ 663) & & & & & & & $<0.001$ \\
\hline Median & & & & & & & \\
\hline Range & & 3.35 & & & & & \\
\hline LDL-cholesterol (n 653) & & & & & & & 0.49 \\
\hline Median & & & & & & & \\
\hline Range & & & & & & & \\
\hline TAG $(n 663)$ & & & & & & & 0.21 \\
\hline Median & & & & & & & \\
\hline Range & & & & & & & \\
\hline General health & & & & & & & \\
\hline Multi-morbidity (n 792)ף & & & & & & & 0.45 \\
\hline Yes & 71 & 564 & 71 & 303 & 74 & 139 & \\
\hline Polypharmacy $(n 788)^{\star \star}$ & & & & & & & 0.63 \\
\hline Yes & 45 & 352 & 45 & 192 & 43 & 79 & \\
\hline Self-rated health ( $n$ 794) & & & & & & & 0.004 \\
\hline Excellent/good & 74 & 588 & 78 & 332 & 66 & 125 & \\
\hline Fair/poor/very poor & 26 & 204 & 22 & 95 & 34 & 63 & \\
\hline Frailty status (score) ( $n$ 785) & & & & & & & 0.59 \\
\hline Robust (0) & 45 & 350 & 43 & 182 & 46 & 85 & \\
\hline Pre-frail (1-2) & 47 & 370 & 48 & 202 & 48 & 89 & \\
\hline Frail $(\geq 3)$ & 8 & 65 & 9 & 37 & 6 & 12 & \\
\hline
\end{tabular}

PASE, Physical Activity Scale for the Elderly; HOMA-IR, homoeostasis model assessment - insulin resistance.

* Overall sample included all countries of birth (Australia, New Zealand, Italy, Greece and other).

$\dagger$ Income source was used as a proxy of income assuming that 'others' have higher income than 'pensioners only'.

¥ Other sources of income includes repatriation pension, veteran's pension, superannuation or other private income, own business/farm/partnership, wage or salary, other or any income source combination.

$\S$ There was a total of forty-eight countries of birth such as England/UK, China, Croatia, Hungary and Malta.

॥ Hypertension was defined as systolic blood pressure $\geq 140 \mathrm{mmHg}$ and diastolic blood pressure $\geq 90 \mathrm{mmHg}^{(32)}$.

I Multi-morbidity was defined as having two or more of these conditions (seventeen).

${ }^{\star *}$ Polypharmacy was defined as the use of five or more regular prescription medicines. 
Table 3. Median daily intake of food groups evaluated by Dietary Guideline Index (DGI-2013), participants' median scores, proportion of participants meeting guidelines, median intake of food groups and variety according to country of birth

(Percentages and numbers; medians and ranges)

\begin{tabular}{|c|c|c|c|c|c|c|c|c|c|c|}
\hline \multirow[b]{3}{*}{ No. of serves } & \multicolumn{5}{|c|}{ Overall } & \multicolumn{4}{|c|}{ Subgroup } & \multirow[b]{3}{*}{$P^{*}$} \\
\hline & \multirow{2}{*}{$\begin{array}{c}\text { Guideline } \\
\text { (serves) }\end{array}$} & \multicolumn{2}{|c|}{$\%$ Meeting guideline } & \multicolumn{2}{|c|}{ DGI food groups intake } & \multicolumn{2}{|c|}{ Australia/New Zealand } & \multicolumn{2}{|c|}{ Italy/Greece } & \\
\hline & & $\%$ & $n$ & Median & Range & Median & Range & Median & Range & \\
\hline Variety† & $\geq 19$ & 49 & 390 & 18 & $4-45$ & 18 & $4-45$ & 18 & $5-42$ & 0.980 \\
\hline Vegetables & $\geq 5$ & 24 & 188 & 3.5 & $0-23.7$ & 3.5 & $0-23.7$ & 3.6 & $1 \cdot 2-21$ & 0.093 \\
\hline Dark green & - & - & & 0.2 & $0-5 \cdot 6$ & 0.2 & $0-2.9$ & 0.2 & $0-2 \cdot 3$ & 0.001 \\
\hline Red/orange & - & - & & 0.9 & $0-7.8$ & 0.8 & $0-7.8$ & 1 & $0 \cdot 1-7 \cdot 6$ & 0.001 \\
\hline Tomatoes & - & - & & 0.2 & $0-5.8$ & 0.2 & $0-2.4$ & 0.5 & $0-5.8$ & $<0.001$ \\
\hline Other red/orange & - & - & & 0.9 & $0-7.8$ & 0.5 & $0-7.8$ & 0.4 & $0-5.8$ & 0.001 \\
\hline Starchy & - & - & & 0.6 & $0-4.2$ & 0.7 & $0-3.7$ & 0.4 & $0-4.1$ & $<0.001$ \\
\hline Potatoes & - & - & & 0.5 & $0-4.2$ & 0.6 & $0-3.5$ & 0.3 & $0-3.8$ & $<0.001$ \\
\hline Other starchy & - & - & & 0 & $0-3 \cdot 3$ & 0 & $0-1 \cdot 7$ & 0 & $0-3 \cdot 3$ & 0.044 \\
\hline Legumes & - & - & & 0.7 & $0-6.6$ & 0 & $0-2.1$ & 0.2 & $0-6.6$ & $<0.001$ \\
\hline Other & - & - & & $1 \cdot 3$ & $0-12 \cdot 8$ & 1.3 & $0-12 \cdot 8$ & $1 \cdot 3$ & $0-9.7$ & 0.715 \\
\hline Fruit & $\geq 2$ & 44 & 349 & 1.8 & $0-11.7$ & 1.8 & $0-9.1$ & 1.8 & $0-11.7$ & 0.885 \\
\hline Fruit juice & - & - & & 0 & $0-8$ & 0 & $0-2 \cdot 9$ & 0 & $0-8$ & 0.031 \\
\hline Grains/cereals & - & - & & 5 & $0 \cdot 1-17$ & 4.8 & $0.1-13.7$ & 4.8 & $1 \cdot 4-17 \cdot 1$ & 0.853 \\
\hline Refined grains & - & - & & $2 \cdot 7$ & $0-17 \cdot 1$ & $2 \cdot 2$ & $0-12.4$ & 3.4 & $0-17 \cdot 1$ & $<0.001$ \\
\hline$\%$ Wholegrains & - & 39 & 313 & $40 \cdot 4$ & $0-100$ & 41.3 & $0-100$ & $42 \cdot 4$ & $0-100$ & $<0.001$ \\
\hline Meat and alternatives & $\geq 2.5$ & 62 & 494 & 2.9 & $0-9.7$ & 2.9 & $0.2-9.7$ & 2.9 & $0-7.3$ & 0.286 \\
\hline Red meats & - & - & & $1 \cdot 1$ & $0-6$ & $1 \cdot 2$ & $0-4.8$ & $1 \cdot 1$ & $0-4.1$ & 0.136 \\
\hline Poultry & - & - & & 0.3 & $0-3.7$ & 0.3 & $0-2.9$ & 0.4 & $0-3 \cdot 7$ & 0.094 \\
\hline Eggs & - & - & & 0.2 & $0-1.5$ & 0.1 & $0-1.4$ & 0.1 & $0-1.2$ & 0.397 \\
\hline Processed meats & - & - & & $0 \cdot 1$ & $0-1.5$ & 0.1 & $0-1.3$ & 0.1 & $0-1.5$ & $<0.001$ \\
\hline Organ meats & - & - & & 0 & $0-0.8$ & 0 & $0-0.8$ & 0 & $0-0$ & 0.035 \\
\hline Seafood & - & - & & 0.3 & $0-3 \cdot 3$ & 0.3 & $0-2 \cdot 3$ & 0 & $0-0$ & 0.058 \\
\hline Nuts seeds & - & - & & 0.2 & $0-6.9$ & 0.2 & $0-6.9$ & 0 & $0-4.7$ & 0.009 \\
\hline Legumes protein & - & - & & 0.05 & $0-4.2$ & 0 & $0-1.3$ & 0.2 & $0-4.2$ & $<0.001$ \\
\hline Soya products & - & - & & 0 & $0-2 \cdot 6$ & 0 & $0-0.5$ & 0 & $0-0.2$ & 0.144 \\
\hline Dairy products and alternatives & $\geq 3.5$ & 9.6 & 76 & 1.7 & $0-9.7$ & 1.9 & $0-9.7$ & 1.4 & $0-6.3$ & $<0.001$ \\
\hline Milk & - & - & & $1 \cdot 1$ & $0-6.7$ & 1.3 & $0-6.5$ & 0.7 & $0-5.4$ & $<0.001$ \\
\hline Cheese & - & - & & 0.3 & $0-5.5$ & 0.3 & $0-3.6$ & 0.4 & $0-5.5$ & 0.002 \\
\hline Yogurt & - & - & & 0 & $0-3.4$ & 0 & $0-1.8$ & 0 & $0-1.2$ & $<0.001$ \\
\hline Milk alternatives & - & - & & 0 & $0-8 \cdot 3$ & 0 & $0-8.3$ & 0 & $0-1 \cdot 1$ & 0.248 \\
\hline Plant protein $\ddagger$ & - & - & & 0.4 & $0-8.5$ & 0.34 & $0-8.5$ & 0.43 & $0-4.8$ & 0.05 \\
\hline Fluid intake§ & $\geq 2 \cdot 6$ & 1 & 8 & $901 \cdot 1$ & $1-4295 \cdot 7$ & 993.6 & $117 \cdot 7-4295 \cdot 7$ & 697.6 & $1-2613 \cdot 4$ & $<0.001$ \\
\hline Water (\%) & $\geq 50$ & $80 \cdot 5$ & 639 & $68 \cdot 8$ & $0-100$ & $67 \cdot 6$ & $0-100$ & $72 \cdot 9$ & $0-100$ & $<0.001$ \\
\hline Discretionary\|l & $\leq 3$ & 0.5 & 3 & $17 \cdot 2$ & $1 \cdot 3-66$ & $18 \cdot 7$ & $2 \cdot 7-58 \cdot 4$ & $13 \cdot 5$ & $3 \cdot 3-66$ & $<0.001$ \\
\hline Added sugar & $\leq 1.5$ & 8.8 & 70 & $7 \cdot 3$ & $0-41.9$ & 0.8 & $0-41.5$ & 5 & $0-41.9$ & $<0.001$ \\
\hline Alcohol & $\leq 2$ & $73 \cdot 6$ & 584 & 0.8 & $0-12.5$ & 0.8 & $0-12.5$ & 1.3 & $0-6.9$ & 0.028 \\
\hline SFAT & $\leq 10$ & 31 & 246 & 11.5 & $3 \cdot 4-33 \cdot 2$ & 8.2 & $2 \cdot 3-27$ & $6 \cdot 8$ & $0.9-21.5$ & $<0.001$ \\
\hline Unsaturated fat ${ }^{\star \star}$ & $\leq 2$ & 1.5 & 1.2 & 8.0 & $0.9-40$ & 9.3 & $1 \cdot 2-30 \cdot 8$ & $12 \cdot 4$ & $1 \cdot 7-40 \cdot 7$ & $<0.001$ \\
\hline Saltt† & $4 \overline{6} 0-2300$ & $70 \cdot 3$ & 558 & $1887 \cdot 0$ & $263 \cdot 2-18628 \cdot 7$ & $1971 \cdot 0$ & $535 \cdot 4-7574 \cdot 7$ & 1702 & $632 \cdot 8-4182$ & $<0.001$ \\
\hline Total DGI-2013ł‡ & - & & & & - & & & & & $<0.001$ \\
\hline
\end{tabular}

* $P$ value for difference of intake between subgroups (Australia and New Zealand-born $v$. Italy and Greece-born participants) derived from Wilcoxon's signed-rank test. Median may not differ between groups, however, values will be ranked differently (as per Wilcoxon's signed-rank test method) hence significant $P$ values for difference.

† Food variety scores were calculated based on the number of different food items consumed in a day; food item was only considered if it belonged to a core food group (grains, fruit, vegetable, protein foods and dairy products); if participant was to consume a different food item to meet their requirements of each food group, he would consume a minimum of nineteen different food items (rounded as one cannot consume half of a new food item.

$\ddagger$ Includes milk alternatives, legumes, soya products, nuts and seeds.

$\S$ Fluid intake included water and water present in milk, fruit juice, tea and coffee.

\| Number of serves of discretionary foods was determined by summing the number of serves of added sugar, solid fat equivalents and alcoholic drinks.

II Amount of SFA as a percentage of total energy.

** Fats naturally occurring in nuts, seeds, avocado, seafood and un-hydrogenated vegetable oils.

†† Salt intake derived from salt added before or after cooking, packaged food items and salt naturally present in food.

拉 Total possible score $=130$.

\section{Discussion}

Our study is the first to assess diet quality in men aged 74 years and older. Overall compliance to the ADG was suboptimal with at least one-third of participants not meeting the recommendation for fruit, grains and meat. Even more concerning, more than half of individuals were not meeting recommendations (under-consuming) for vegetables, dairy products and alternatives and fluid but over-consuming added sugar, unsaturated fat and SFA fat, and discretionary foods. The main factors associated with DGI-2013 were education, income, smoking status and physical activity level.

Several studies have found an association between lower income and poorer dietary quality ${ }^{(25,54-57)}$. Nutritious and 
Table 4. Statistical analyses investigating the association between health measures/outcomes and Dietary Guideline Index (DGI-2013) scores in Concord Health and Ageing in Men Project $(n 794)$

(Estimates and $95 \%$ confidence intervals)

\begin{tabular}{|c|c|c|c|c|}
\hline Outcomes & Coefficient & Estimate & $95 \% \mathrm{Cl}$ & $P$ \\
\hline \multirow{9}{*}{ HOMA-IR } & Model 1 & & & \\
\hline & Intercept & 0.641 & $-0.008,1.290$ & 0.05 \\
\hline & Total score & 0.004 & $-0.004,-0.012$ & 0.22 \\
\hline & Model 2 & & & \\
\hline & Intercept & 0.834 & $0.112,1.557$ & 0.024 \\
\hline & Total score & 0.004 & $-0.004,0.012$ & 0.258 \\
\hline & Education $_{\text {trade/apprenticeship/certificate/diploma }}$ & -0.210 & $-0.432,0.012$ & 0.063 \\
\hline & Education $_{\text {high school and below }}$ & -0.115 & $-0.344,0.115$ & 0.328 \\
\hline & Income $_{\text {other }}$ & -0.062 & $-0.214,0.09$ & 0.424 \\
\hline \multirow[t]{9}{*}{ LDL-cholesterol } & Model 1 & & & \\
\hline & Intercept & $2 \cdot 616$ & $2.007,3.226$ & $<0.001$ \\
\hline & Total score & -0.001 & $-0.007,0.006$ & 0.82 \\
\hline & Model 2 & & & \\
\hline & Intercept & 2.410 & $1.731,3.091$ & $<0.001$ \\
\hline & Total score & 0.001 & $-0.007,0.008$ & 0.884 \\
\hline & Education $_{\text {trade/apprenticeship/certificate/diploma }}$ & 0.139 & $-0.071,0.349$ & 0.194 \\
\hline & Education $_{\text {high school and below }}$ & $0 \cdot 109$ & $-0.108,0.325$ & 0.325 \\
\hline & Income $_{\text {other }}$ & -0.034 & $-0.177,0.11$ & 0.646 \\
\hline \multirow{9}{*}{ HDL-cholesterol } & Model 1 & & & \\
\hline & Intercept & 1.702 & $1.428,1.976$ & $<0.001$ \\
\hline & Total score & -0.003 & $-6.25 \times 10^{-0.3},-4.50 \times 10^{-04}$ & 0.02 \\
\hline & Model 2 & & & \\
\hline & Intercept & 1.950 & $1.65,2 \cdot 252$ & $<0.001$ \\
\hline & Total score & -0.005 & $-0.009,-0.003$ & 0.001 \\
\hline & Education $_{\text {trade/apprenticeship/certificate/diploma }}$ & -0.089 & $-0.182,0.004$ & 0.059 \\
\hline & Education $_{\text {high school and below }}$ & $-0 \cdot 161$ & $-0.257,-0.066$ & 0.001 \\
\hline & Income $_{\text {other }}$ & 0.072 & $0.009,0.136$ & 0.026 \\
\hline \multirow[t]{9}{*}{ TAG } & Model 1 & & & \\
\hline & Intercept & 1.574 & $1 \cdot 134,2 \cdot 014$ & $<0.001$ \\
\hline & Total score & -0.003 & $-0.008,0.001$ & 0.002 \\
\hline & Model 2 & & & \\
\hline & Intercept & 1.328 & $0.839,1.817$ & $<0.001$ \\
\hline & Total score & -0.002 & $-0.007,0.004$ & 0.500 \\
\hline & Education $_{\text {trade/apprenticeship/certificate/diploma }}$ & 0.108 & $-0.043,0.259$ & 0.159 \\
\hline & Education $_{\text {high school and below }}$ & 0.162 & $0.007,0.317$ & 0.041 \\
\hline & Income $_{\text {other }}$ & -0.065 & $-0.168,0.038$ & 0.213 \\
\hline \multirow[t]{9}{*}{ Waist:hip ratio } & Model 1 & & & \\
\hline & Intercept & 1.056 & $1.02 \times 10^{+00}, 1.09 \times 10^{+00}$ & $<0.001$ \\
\hline & Total score & -0.001 & $-1.16 \times 10^{-3}, 3.80 \times 10^{-04}$ & $<0.001$ \\
\hline & Model 2 & & & \\
\hline & Intercept & 1.037 & $0.997,1.077$ & $<0.001$ \\
\hline & Total score & -0.001 & $-0.002,-0.001$ & 0.002 \\
\hline & Education $_{\text {trade/apprenticeship/certificate/diploma }}$ & 0.016 & $0.004,0.029$ & 0.012 \\
\hline & Education $_{\text {high school and below }}$ & 0.013 & $0.001,0.027$ & 0.044 \\
\hline & Income $_{\text {other }}$ & -0.009 & $-0.018,0.001$ & 0.050 \\
\hline \multirow[t]{9}{*}{$\mathrm{BMI}$} & Model 1 & & & \\
\hline & Intercept & 30.05 & $27.57,32.52$ & $<0.001$ \\
\hline & Total score & -0.025 & $-0.005,0.001$ & 0.06 \\
\hline & Model 2 & & & \\
\hline & Intercept & 27.981 & $25 \cdot 288,30.676$ & $<0.001$ \\
\hline & Total score & -0.011 & $-0.039,0.016$ & 0.412 \\
\hline & Education $_{\text {trade/apprenticeship/certificate/diploma }}$ & 1.002 & $0.178,1.828$ & 0.017 \\
\hline & Education $_{\text {high school and below }}$ & 1.539 & $0.682,2.398$ & 0.000 \\
\hline & Income $_{\text {other }}$ & -0.532 & $-1.116,0.052$ & 0.074 \\
\hline \multirow[t]{9}{*}{ Number of co-morbidities } & Model 1 & & & \\
\hline & Intercept & 0.92 & $0.540,1.312$ & $<0.001$ \\
\hline & Total score & $1.00 \times 10^{-04}$ & $-0.004,0.004$ & 0.96 \\
\hline & Model 2 & & & \\
\hline & Intercept & 0.940 & $0.515,1.367$ & $<0.001$ \\
\hline & Total score & $2.40 \times 10^{-04}$ & $-0.005,0.005$ & 0.912 \\
\hline & Education $_{\text {trade/apprenticeship/certificate/diploma }}$ & -0.049 & $-0.18,0.083$ & 0.465 \\
\hline & Education $_{\text {high school and below }}$ & -0.006 & $-0.141,0.129$ & 0.925 \\
\hline & Income $_{\text {other }}$ & -0.008 & $-0.101,0.085$ & 0.864 \\
\hline \multirow[t]{3}{*}{ Number of medications } & Model 1 & & & \\
\hline & Intercept & 1.58 & $1 \cdot 15,2 \cdot 02$ & $<0.001$ \\
\hline & Total score & -0.001 & $-0.006,0.004$ & 0.69 \\
\hline
\end{tabular}


Table 4. Continued

\begin{tabular}{|c|c|c|c|c|}
\hline Outcomes & Coefficient & Estimate & $95 \% \mathrm{Cl}$ & $P$ \\
\hline & Model 2 & & & \\
\hline & Intercept & 1.692 & $1 \cdot 211,2 \cdot 173$ & $<0.001$ \\
\hline & Total score & -0.001 & $-0.006,0.004$ & 0.675 \\
\hline & Education $_{\text {trade/apprenticeship/certificate/diploma }}$ & -0.080 & $-0.228,0.068$ & 0.288 \\
\hline & Education $_{\text {high school and below }}$ & -0.069 & $-0.221,0.084$ & 0.376 \\
\hline & Income $_{\text {other }}$ & -0.056 & $-0.16,0.049$ & 0.296 \\
\hline \multirow{9}{*}{ Blood pressure high-normal } & Model 1 & & & \\
\hline & Intercept & -0.119 & $-2 \cdot 519,2 \cdot 281$ & 0.92 \\
\hline & Total score & -0.008 & $-0.033,0.018$ & 0.56 \\
\hline & Model 2 & & & \\
\hline & Intercept & -0.544 & $-3 \cdot 201,2 \cdot 113$ & 0.69 \\
\hline & Total score & -0.008 & $-0.035,0.018$ & 0.54 \\
\hline & Education $_{\text {trade/apprenticeship/certificate/diploma }}$ & 0.517 & $-0.319,1.352$ & 0.23 \\
\hline & Education $_{\text {high school and below }}$ & 0.277 & $-0.582,1.136$ & 0.53 \\
\hline & Income $_{\text {other }}$ & 0.213 & $-0.382,0.808$ & 0.48 \\
\hline \multirow{9}{*}{ Blood pressure $_{\text {hypertensive }}$} & Model 1 & & & \\
\hline & Intercept & $1 \cdot 280$ & $-0 \cdot 257,2 \cdot 816$ & $0 \cdot 10$ \\
\hline & Total score & -0.001 & $-0.018,0.015$ & 0.88 \\
\hline & Model 2 & & & \\
\hline & Intercept & 0.969 & $-0.716,2 \cdot 654$ & 0.26 \\
\hline & Total score & $<0.001$ & $-0.016,0.017$ & 0.96 \\
\hline & Education $_{\text {trade/apprenticeship/certificate/diploma }}$ & 0.415 & $-0.088,0.918$ & 0.11 \\
\hline & Education $_{\text {high school and below }}$ & $0 \cdot 140$ & $-0.372,0.652$ & 0.59 \\
\hline & Income $_{\text {other }}$ & -0.139 & $-0.509,0.230$ & 0.46 \\
\hline \multirow[t]{9}{*}{ Frailty status pre-frail } & Model 1 & & & \\
\hline & Intercept & 0.895 & $-0.433,2.222$ & 0.18 \\
\hline & Total score & -0.009 & $-0.023,0.005$ & 0.21 \\
\hline & Model 2 & & & \\
\hline & Intercept & $1 \cdot 229$ & $-0.242,2 \cdot 701$ & 0.10 \\
\hline & Total score & -0.011 & $-0.025,0.004$ & 0.16 \\
\hline & Education $_{\text {trade/apprenticeship/certificate/diploma }}$ & -0.321 & $-0.769,0.127$ & 0.16 \\
\hline & Education high school and below & -0.211 & $-0.677,0.256$ & 0.36 \\
\hline & Income $_{\text {other }}$ & 0.059 & $-0.252,0.371$ & 0.71 \\
\hline \multirow{9}{*}{ Frailty status $_{\text {frail }}$} & Model 1 & & & \\
\hline & Intercept & 2.404 & $0.178,4.630$ & 0.03 \\
\hline & Total score & -0.045 & $-0.069,-0.020$ & $<0.001$ \\
\hline & Model 2 & & & \\
\hline & Intercept & 3.042 & $0.596,5.489$ & 0.01 \\
\hline & Total score & -0.048 & $-0.073,-0.023$ & $<0.001$ \\
\hline & Education $_{\text {trade/apprenticeship/certificate/diploma }}$ & -0.916 & $-1 \cdot 707,-0.124$ & 0.02 \\
\hline & Education $_{\text {high school and below }}$ & -0.369 & $-1.138,0.400$ & 0.35 \\
\hline & Income $_{\text {other }}$ & 0.316 & $-0.264,0.897$ & 0.29 \\
\hline
\end{tabular}

Model 1, unadjusted; model 2, adjusted for education and income; HOMA-IR, homoeostasis model assessment - insulin resistance (high HOMA-IR values indicate low insulin sensitivity (insulin resistance)).

healthy foods tend to be more expensive ${ }^{(58,59)}$ whereas energy dense and nutrition poor diets tend to be cheaper ${ }^{(60)}$, therefore cost may be a large barrier for older adults - particularly those living on the Age Pension - when choosing and purchasing foods. Furthermore, processed foods are cheaper and more palatable making them more attractive to older individuals who tend to have poor gustatory function ${ }^{(61)}$ and, among older men, limited cooking facilities and/or ability ${ }^{(62)}$. Education and nutritional knowledge tend to correlate ${ }^{(63)}$, therefore it is not surprising that less educated individuals are more likely to have poor compliance to the ADG. Similarly, poor health behaviours' such as low physical activity and smoking are often associated with poor nutritional habits ${ }^{(18,64-66)}$. Morabia \& Wynder ${ }^{(64)}$ investigated the association between dietary intake and smoking status of 7860 subjects aged 25-74 years and found that smokers consumed less fruit and vegetables, more alcohol and coffee than never smokers; male smokers consumed more meat and less cereals than those who were never smokers.
Compared with the general population of similar age and sex, that is, the latest nationally representative Australian Health Survey (AHS) $)^{(67)}$, CHAMP participants' intakes of vegetable, meat and alternatives, dairy products and alternatives and fluid intakes were higher, however this difference may be because of the difference in dietary assessment method used in the two studies (AHS used 24-h recall $v$. DHQ in current study). Regarding higher vegetable intake in CHAMP participants, one explanation for the difference between AHS and the present study results may be related to the large proportion of CHAMP participants with a Mediterranean background - known to consume more vegetables ${ }^{(7)}$. Income may also play a role in explaining some of the differences in intake between the two studies; foods high in protein (e.g. dairy products and meat) tend to be more expensive than carbohydrate rich foods ${ }^{(68)}$, and given that at least $40 \%$ of CHAMP participants are likely to be on higher income (as per income source), one can assume that they have access to high protein foods. 
Table 5. Analyses investigating the association between health measures and indices and Dietary Guideline Index (DGI-2013) scores in Concord Health and Ageing in Men Project according to country of birth (Australia/New Zealand $v$. Italy/Greece) $(n$ 615) (Estimates and $95 \%$ confidence intervals)

\begin{tabular}{|c|c|c|c|c|}
\hline Outcomes & Coefficient & Estimate & $95 \% \mathrm{Cl}$ & $P$ \\
\hline \multirow[t]{7}{*}{ HOMA-IR } & Intercept & 1.448 & $0.541-2.355$ & 0.002 \\
\hline & $\mathrm{COB}_{\text {Italy/Greece }}$ & $-2 \cdot 061$ & $-3.609--0.513$ & 0.009 \\
\hline & Total score & -0.003 & $-0.013-0.007$ & 0.523 \\
\hline & Education $_{\text {trade/apprenticeship/certificate/diploma }}$ & -0.164 & $-0.399-0.071$ & 0.170 \\
\hline & Education $_{\text {high school and below }}$ & -0.136 & $-0.391-0.119$ & 0.299 \\
\hline & Income $_{\text {other }}$ & -0.069 & $-0.234-0.096$ & 0.412 \\
\hline & $\mathrm{COB}_{\text {Italy/Greece: Total score }}$ & 0.024 & $0.008-0.04$ & 0.005 \\
\hline \multirow[t]{7}{*}{ LDL-cholesterol } & Intercept & 1.483 & $0.558-2.408$ & 0.002 \\
\hline & $\mathrm{COB}_{\text {Italy/Greece }}$ & $1 \cdot 12$ & $-0.464-2.704$ & 0.166 \\
\hline & Total score & 0.008 & $-0.002-0.018$ & 0.078 \\
\hline & Education $_{\text {trade/apprenticeship/certificate/diploma }}$ & 0.264 & $0.021-0.507$ & 0.034 \\
\hline & Education $_{\text {high school and below }}$ & 0.249 & $-0.016-0.514$ & 0.065 \\
\hline & Income $_{\text {other }}$ & -0.001 & $-0.17-0 \cdot 168$ & 0.988 \\
\hline & $\mathrm{COB}_{\text {Italy/Greece: total score }}$ & -0.012 & $-0.03-0.006$ & 0.18 \\
\hline \multirow[t]{7}{*}{ HDL-cholesterol } & Intercept & 1.854 & $1.446-2 \cdot 262$ & $<0.001$ \\
\hline & $\mathrm{COB}_{\text {Italy/Greece }}$ & -0.316 & $-1.018-0.386$ & 0.377 \\
\hline & Total score & -0.005 & $-0.009--0.001$ & 0.023 \\
\hline & Education $_{\text {trade/apprenticeship/certificate/diploma }}$ & -0.028 & $-0.134-0.078$ & 0.606 \\
\hline & Education $_{\text {high school and below }}$ & -0.053 & $-0.169-0.063$ & 0.368 \\
\hline & Income $_{\text {other }}$ & 0.072 & $-0.002-0.146$ & 0.057 \\
\hline & $\mathrm{COB}_{\text {Italy/Greece: }}$ total score & 0.002 & $-0.006-0.01$ & 0.611 \\
\hline \multirow[t]{7}{*}{ TAG } & Intercept & 1.578 & $0.904-2.252$ & $<0.001$ \\
\hline & $\mathrm{COB}_{\text {traly/Greece }}$ & -0.161 & $-1.321-0.999$ & 0.786 \\
\hline & Total score & -0.004 & $-0.01-0.002$ & 0.221 \\
\hline & Education $_{\text {trade/apprenticeship/certificate/diploma }}$ & 0.094 & $-0.082-0.27$ & 0.298 \\
\hline & Education $_{\text {high school and below }}$ & $0 \cdot 159$ & $-0.033-0.351$ & 0.105 \\
\hline & Income $_{\text {other }}$ & -0.062 & $-0.185-0.061$ & 0.322 \\
\hline & $\mathrm{COB}_{\text {Italy/Greece: }}$ total score & 0.002 & $-0.01-0.014$ & 0.778 \\
\hline \multirow{7}{*}{ Waist:hip ratio } & Intercept & 1.035 & $0.986-1.084$ & $<0.001$ \\
\hline & $\mathrm{COB}_{\text {Italy/Greece }}$ & -0.015 & $-0.105-0.075$ & 0.746 \\
\hline & Total score & -0.001 & $-0.001--0.001$ & 0.02 \\
\hline & Education $_{\text {trade/apprenticeship/certificate/diploma }}$ & 0.006 & $-0.008-0.02$ & 0.4 \\
\hline & Education $_{\text {high school and below }}$ & 0.002 & $-0.012-0.016$ & 0.786 \\
\hline & Income $_{\text {other }}$ & -0.005 & $-0.015-0.005$ & 0.308 \\
\hline & $\mathrm{COB}_{\text {Italy/Greece: }}$ total score & 0.000 & $0.000-0.000$ & 0.506 \\
\hline \multirow[t]{7}{*}{$\mathrm{BMI}$} & Intercept & 29.377 & $25 \cdot 827-32 \cdot 927$ & $<0.001$ \\
\hline & $\mathrm{COB}_{\text {Italy/Greece }}$ & -0.404 & $-6 \cdot 692-5 \cdot 884$ & 0.9 \\
\hline & Total score & -0.022 & $-0.057-0.013$ & 0.216 \\
\hline & Education $_{\text {trade/apprenticeship/certificate/diploma }}$ & 0.318 & $-0.627-1.263$ & 0.51 \\
\hline & Education $_{\text {high school and below }}$ & 0.445 & $-0.584-1.474$ & 0.397 \\
\hline & Income $_{\text {other }}$ & -0.409 & $-1.093-0.275$ & 0.242 \\
\hline & $\mathrm{COB}_{\text {Italy/Greece: }}$ total score & 0.024 & $-0.045-0.093$ & 0.495 \\
\hline \multirow[t]{7}{*}{ Number of co-morbidities } & Intercept & 1.347 & $0.784-1.91$ & $<0.001$ \\
\hline & $\mathrm{COB}_{\text {Italy/Greece }}$ & -1.029 & $-2.031--0.027$ & 0.045 \\
\hline & Total score & -0.003 & $-0.009-0.003$ & 0.339 \\
\hline & Education $_{\text {trade/apprenticeship/certificate/diploma }}$ & $-0 \cdot 157$ & $-0.306--0.008$ & 0.04 \\
\hline & Education $_{\text {high school and below }}$ & -0.114 & $-0.275-0.047$ & 0.163 \\
\hline & Income $_{\text {other }}$ & -0.062 & $-0.172-0.048$ & 0.268 \\
\hline & $\mathrm{COB}_{\text {Italy/Greece: }}$ total score & 0.011 & $-0.001-0.023$ & 0.039 \\
\hline \multirow[t]{7}{*}{ Number of medications } & Intercept & 2.062 & $1.433-2.691$ & $<0.001$ \\
\hline & $\mathrm{COB}_{\text {Italy/Greece }}$ & -1.583 & $-2.722--0.444$ & 0.007 \\
\hline & Total score & -0.005 & $-0.011-0.001$ & 0.154 \\
\hline & Education $_{\text {trade/apprenticeship/certificate/diploma }}$ & -0.137 & $-0.306-0.032$ & 0.111 \\
\hline & Education $_{\text {high school and below }}$ & -0.120 & $-0.306-0.060$ & 0.196 \\
\hline & Income $_{\text {other }}$ & -0.070 & $-0.192-0.052$ & 0.265 \\
\hline & $\mathrm{COB}_{\text {Italy/Greece: total score }}$ & 0.017 & $0.005-0.029$ & 0.005 \\
\hline \multirow{7}{*}{ Blood pressure $_{\text {high-normal }}$} & Intercept & $-1 \cdot 11$ & $-4.793-2.566$ & 0.55 \\
\hline & $\mathrm{COB}_{\text {Italy/Greece }}$ & -0.666 & $-7.004-5 \cdot 678$ & 0.84 \\
\hline & Total score & 0.001 & $-0.035-0.037$ & 0.96 \\
\hline & Education $_{\text {trade/apprenticeship/certificate/diploma }}$ & $0 \cdot 215$ & $-0 \cdot 760-1 \cdot 190$ & 0.66 \\
\hline & Education $_{\text {high school and below }}$ & -0.270 & $-1.331-0.790$ & 0.62 \\
\hline & Income $_{\text {other }}$ & 0.228 & $-0.496-0.951$ & 0.54 \\
\hline & $\mathrm{COB}_{\text {Italy/Greece: }}$ total score & 0.011 & $-0.058-0.080$ & 0.75 \\
\hline \multirow{4}{*}{ Blood pressure hypertensive } & Intercept & 1.583 & $-0.734-3.900$ & 0.18 \\
\hline & $\mathrm{COB}_{\text {Italy/Greece }}$ & $-3 \cdot 368$ & $-7.499-0.763$ & 0.11 \\
\hline & Total score & -0.002 & $-0.025-0.021$ & 0.87 \\
\hline & Education $_{\text {trade/apprenticeship/certificate/diploma }}$ & 0.015 & $-0.613-0.643$ & 0.96 \\
\hline
\end{tabular}


Table 5. Continued

\begin{tabular}{|c|c|c|c|c|}
\hline Outcomes & Coefficient & Estimate & $95 \% \mathrm{Cl}$ & $P$ \\
\hline & Education $_{\text {high school and below }}$ & -0.332 & $-0.997-0.333$ & 0.33 \\
\hline & Income $_{\text {other }}$ & -0.240 & $-0.695-0.215$ & 0.30 \\
\hline & $\mathrm{COB}_{\text {Italy/Greece: }}$ total score & 0.038 & $-0.007-0.083$ & $0 \cdot 10$ \\
\hline \multirow[t]{7}{*}{ Frailty status pre-frail } & Intercept & $2 \cdot 386$ & $0.292-4.478$ & 0.03 \\
\hline & $\mathrm{COB}_{\text {Italy/Greece }}$ & $-3 \cdot 355$ & $-6 \cdot 89-0 \cdot 179$ & 0.06 \\
\hline & Total score & -0.022 & $-0.043--0.001$ & 0.04 \\
\hline & Education $_{\text {trade/apprenticeship/certificate/diploma }}$ & $-0 \cdot 280$ & $-0.812-0.251$ & 0.30 \\
\hline & Education $_{\text {high school and below }}$ & -0.098 & $-0.678-0.482$ & 0.74 \\
\hline & Income $_{\text {other }}$ & -0.026 & $-0.406-0.354$ & 0.89 \\
\hline & $\mathrm{COB}_{\text {Italy/Greece: }}$ total score & 0.034 & $-0.004-0.073$ & 0.08 \\
\hline \multirow[t]{7}{*}{ Frailty status $_{\text {frail }}$} & Intercept & 5.993 & $2.644-9.343$ & $<0.001$ \\
\hline & $\mathrm{COB}_{\text {Italy/Greece }}$ & -9.592 & $-16 \cdot 296--2 \cdot 889$ & 0.01 \\
\hline & Total score & -0.080 & $-0.115--0.045$ & $<0.001$ \\
\hline & Education $_{\text {trade/apprenticeship/certificate/diploma }}$ & -0.896 & $-1.888-0.096$ & 0.08 \\
\hline & Education $_{\text {high school and below }}$ & -0.100 & $-1.089-0.888$ & 0.84 \\
\hline & Income $_{\text {other }}$ & 0.264 & $-0.458-0.986$ & 0.47 \\
\hline & $\mathrm{COB}_{\text {Italy/Greece: }}$ total score & 0.100 & $0.027-0.172$ & 0.01 \\
\hline
\end{tabular}

$\mathrm{COB}$, country of birth; HOMA-IR, homoeostasis model assessment - insulin resistance (high HOMA-IR values indicate low insulin sensitivity (insulin resistance)).
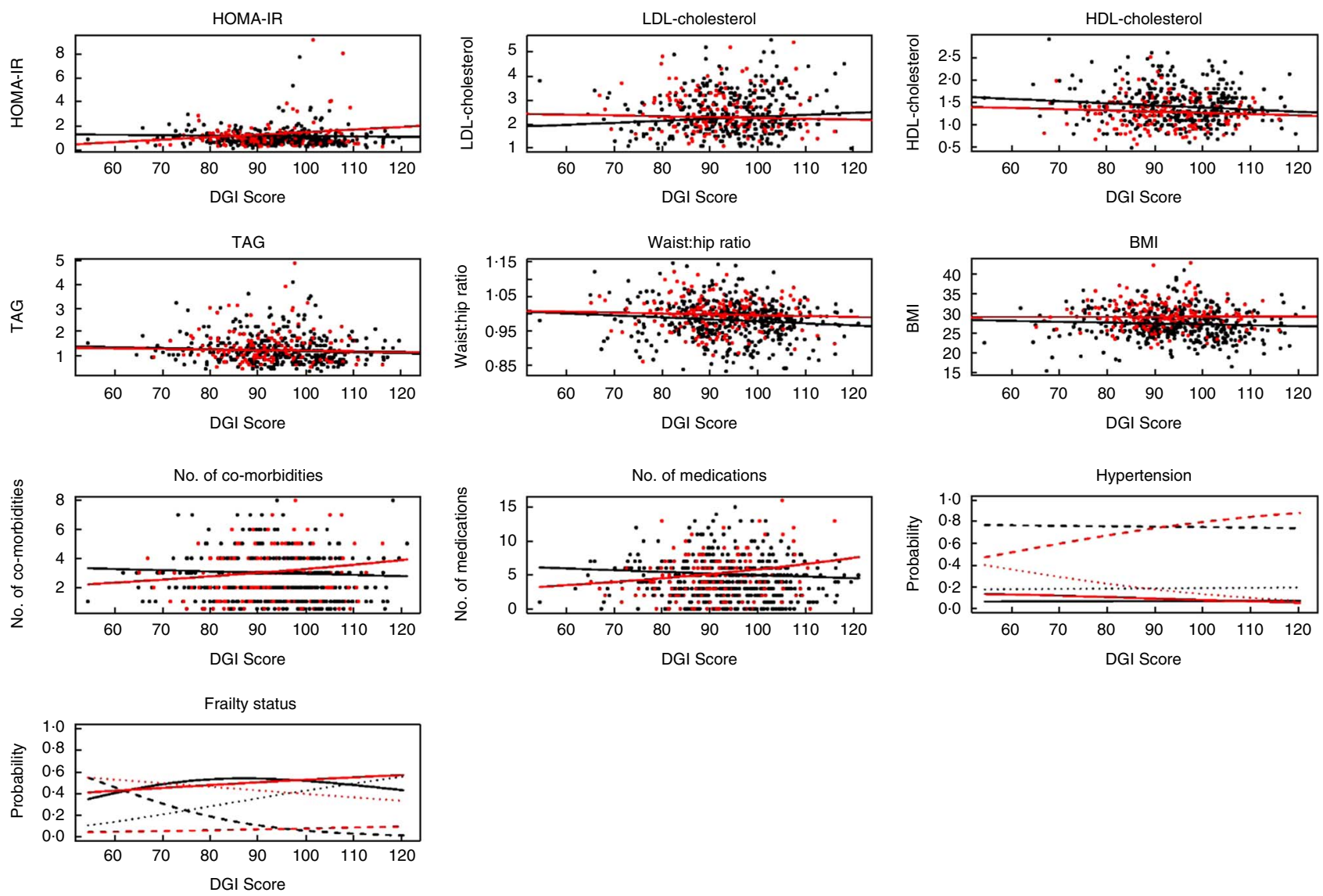

Fig. 1. Graphical representation of the association between health outcomes and Dietary Guideline Index (DGI)-2013 scores according to country of birth. HOMA-IR, homoeostasis model assessment - insulin resistance; __ . Australia/New Zealand; __ , Italy/Greece; __ , high normal/pre-frail; _- - , hypertensive/frail; , normal/robust. Linear regression used to investigate the association between continuous variables (HOMA-IR, LDL-cholesterol, HDL-cholesterol, TAG, waist: hip ratio and $\mathrm{BMI}$ ) and DGI-2013 scores, general linear model was used to investigate the association between interval variables (number of co-morbidities and number of medications) and DGI-2013 scores, and multinomial analysis was used to investigate the association between nominal variables (hypertension and frailty status) and DGI-2013 scores. Models were adjusted for education, income as those were significantly different between Australian/ New Zealander born and Italian/ Greek born participants (Table 2) and were also associated with DGI-2013 scores (Tables 4 and 5).

Two of the ADG are known to have a direct effect on HDL-cholesterol levels: limiting consumption of SFA and consuming a small allowance of unsaturated fat ${ }^{(17)}$. In the present study, we found that high DGI scores (i.e. better compliance with ADG) were associated with lower HDL-cholesterol levels. One potential reason for this may be the limitation in unsaturated fat. 
Although one would expect that better compliance with dietary guidelines would result in healthier HDL-cholesterol levels (i.e. higher levels), other non-dietary factors such as obesity and smoking status, presence of the metabolic syndrome, hypertriacylglycerolaemia and even socioeconomic status may also influence HDL-cholesterol levels ${ }^{(69)}$.

In this study, we found that high DGI scores were not associated with some indicators of better overall health such as fewer co-morbidities or number of medications. There are a number of potential explanations for this: first, ageing in itself is an important factor in the development of some of the health issues common in older age; second, some factors such as genetics, for example, have an impact on the relationship between nutrition and health measures and indices but cannot be accounted for. Similarly, although we have adjusted for a number of factors known to have an impact in those associations, there may still be some factors not yet identified that may confound these associations.

A recent systematic review involving both longitudinal and cross-sectional data, showed that better diet - as measured by a variety of dietary assessments and dietary indices - was associated with successful ageing as defined by better quality of life as well as good mental and physical health ${ }^{(5)}$. DGI is based on ADG, which provides evidence based guidelines on food types and quantities that are associated with a reduction in morbidity and mortality ${ }^{(17)}$. It follows that compliance with the dietary guidelines therefore, should result in better health measures and indices ${ }^{(70-72)}$. In our study we found that overall, although not always statistically significant, good compliance to the DGI was associated with better health measures and indices.

Evidence suggests that dietary preferences established in younger ages can influence food choices in later life ${ }^{(73)}$; therefore, it is likely that older individuals will follow the same dietary patterns as those established in their earlier age and COB. This may explain the observed higher intake of alcohol and unsaturated fats as well as significantly higher intake of legumes and non-starchy vegetables (Mediterranean dietary pattern) amongst Italian/Greek-born men. Surprisingly, Italian/ Greek-born participants with better compliance to the ADG had a tendency to poorer health measures and indices, in particular number of co-morbidities. Mediterranean dietary patterns have been shown to have beneficial effects on several age-related health outcomes ${ }^{(7)}$ and this may explain, at least in part, why Italian and Greek-born men have similar health to Australian and New Zealand-born men despite lower DGI scores. This also suggests that a dietary index developed for the general population may not be suitable for or accepted by those from diverse ethnic backgrounds. The poorer health in Italian and Greek migrants with greater compliance to the ADG could reflect the loss of the protective Mediterranean dietary pattern in this group but could equally be the result of reverse causality where men have changed their diets to conform more closely to the ADG in response to ill health.

\section{Strengths and limitations}

One of the main strengths of this study was the use of a validated dietitian-administered diet history questionnaire to assess dietary intake of its participants. DHQ is a retrospective method is particularly indicated for older people because their diets tend to be consistent over long periods of time, it does not rely on short-term memory and it uses a much more interactive approach than other methods ${ }^{(12,74-76)}$. Furthermore, diet histories have low respondent burden, which may improve response rates among older people and they require no literacy or numeracy skills from participants ${ }^{(77-79)}$, making them suitable for participants from culturally and linguistically diverse backgrounds. Another advantage of using data derived from diet history questionnaires is that no pre-established serves and frequency are used, that gives a good notion of variety of food consumed and also permits us to proportionally score guidelines related to moderate and limited intake. The present study also had some limitations. First, we used data from a cross-sectional observational study, which precludes the investigation of causal mechanisms. Furthermore, when assessing these findings, it is important to take into account important 'survival effects' - that is, individuals with poor nutrition tend to be less likely to live to the advanced ages examined in this study ${ }^{(3)}$. Second, as in most studies on nutritional epidemiology, diet was self-reported and measurement bias may be present; however, measurement bias is likely to have been non-differential with regards to measures and indices and so will have led to underestimation of associations, rather than causing spurious associations. Similarly, self-reported food intake may have been influenced by participants' desire to gain approval from interviewer/researcher ${ }^{(80)}$ based on what is believed to be 'healthy'. Finally, adaptation of DGI-2013 was necessary regarding salt and animal fat trimming; this resulted in a DGI composed of a mix of food and nutrient-based DGI score which may not be as practical in a clinical setting as a food-based dietary index.

\section{Conclusion}

In conclusion, this cross-sectional study has demonstrated that the diet of Australian men aged $\geq 74$ years is suboptimal according to ADG. However, for participants with a Mediterranean background, having poor compliance to ADG was not associated with poorer health. These findings highlight the need for development of dietary guidelines that are more acknowledge and encourage dietary patterns from culturally diverse groups. Further investigation is required to confirm these findings, particularly in longitudinal studies.

\section{Acknowledgements}

The authors thank all the CHAMP's staff and participants for their contributions and Sydney Medical School Foundation for their support.

The CHAMP study is funded by the National Health and Medical Research Council (301916) and the Ageing And Alzheimers Institute.

The CHAMP study was designed by R. G. C., V. N., D. J. H., M. J. S., D. G. L. C., L. M. W. and F. M. B.. R. V. R., V. H. and A. K. G. developed the concepts for this paper. R. V. R. and V. H. designed the protocol for diet history. R. V. R. collected and trained the staff for nutritional data collection, coded foods, 
conducted all the data analyses and wrote the first draft of the manuscript. A. M. S. oversaw statistical analyses. V. H., A. M. S., A. K. G., R. G. C., F. M. B., V. N., L. M. W., D. J. H., M. J. S., S. J. S., F. S., M. A.-F. and D. G. L. C. collaborated in writing. All authors reviewed and approved the final version of the manuscript. All authors had primary responsibility for final content.

None of the authors has any conflicts of interest to declare.

\section{Supplementary material}

For supplementary material/s referred to in this article, please visit https://doi.org/10.1017/S0007114517001738

\section{References}

1. World Health Organization (2015) Health topics - ageing http://www.who.int/topics/ageing/en/ (accessed March 2015).

2. Mathers JC (2013) Nutrition and ageing: knowledge, gaps and research priorities. Proc Nutr Soc 72, 246-250.

3. Kendig H, Browning CJ, Thomas SA, et al. (2014) Health, lifestyle, and gender influences on aging well: an Australian longitudinal analysis to guide health promotion. Front Public Health 2, 70 .

4. Kendig H, McDonald P \& Piggott J (2016) Population Ageing and Australia's Future. Acton, ACT, Australia: ANU Press.

5. Milte CM \& McNaughton SA (2016) Dietary patterns and successful ageing: a systematic review. Eur J Nutr 55, 423-450.

6. Le Couteur DG, Solon-Biet S, Wahl D, et al. (2016) New Horizons: dietary protein, ageing and the Okinawan ratio. Age Ageing 45, 443-447.

7. Sofi F, Cesari F, Abbate R, et al. (2008) Adherence to Mediterranean diet and health status: meta-analysis. BMJ 337, a1344.

8. Wakimoto P \& Block G (2001) Dietary intake, dietary patterns, and changes with age: an epidemiological perspective. J Gerontol A Biol Sci Med Sci 56, 65-80.

9. Morley JE (2001) Decreased food intake with aging. J Gerontol A Biol Sci Med Sci 56, 81-88.

10. Löwik M, Westenbrink S, Hulshof K, et al. (1989) Nutrition and aging: dietary intake of 'apparently healthy' elderly (Dutch Nutrition Surveillance System). I Am Coll Nutr 8, 347-356.

11. Meydani $M$ (2001) Nutrition interventions in aging and age-associated disease. Ann N Y Acad Sci 928, 226-235.

12. Hankin JH (1989) Development of a diet history questionnaire for studies of older persons. Am J Clin Nutr 50, 1121-1127.

13. Baker AH \& Wardle J (2003) Sex differences in fruit and vegetable intake in older adults. Appetite 40, 269-275.

14. Simpson SJ, Le Couteur DG \& Raubenheimer D (2015) Putting the balance back in diet. Cell 161, 18-23.

15. Hu FB (2002) Dietary pattern analysis: a new direction in nutritional epidemiology. Curr Opin Lipidol 13, 3-9.

16. Raubenheimer D \& Simpson SJ (2016) Nutritional ecology and human health. Ann Rev Nutr 36, 603-626.

17. National Health and Medical Research Council (2013) Eat for Health: Australian Dietary Guidelines. Canberra: National Health and Medical Research Council.

18. Thorpe M, Milte C, Crawford D, et al. (2016) A revised Australian Dietary Guideline Index and its association with key sociodemographic factors, health behaviors and body mass index in peri-retirement aged adults. Nutrients $\mathbf{8}, 160$.

19. Cumming RG, Handelsman D, Seibel MJ, et al. (2009) Cohort Profile: the Concord Health and Ageing in Men Project (CHAMP). Int J Epidemiol 38, 374-378.

20. Waern RV, Cumming RG, Blyth F, et al. (2015) Adequacy of nutritional intake among older men living in Sydney,
Australia: findings from the Concord Health and Ageing in Men Project (CHAMP). Br J Nutr 114, 812-821.

21. Waern RVR, Cumming R, Travison T, et al. (2015) Relative validity of a diet history questionnaire against a four-day weighed food record among older men in Australia: the Concord Health and Ageing in Men Project (CHAMP). J Nutr Health Aging 19, 603-610.

22. Burke BS (1947) The dietary history as a tool in research. J Am Diet Assoc 23, 1041-1046.

23. Neale EP, Probst YC \& Tapsell LC (2016) Development of a matching file of Australian food composition databases (AUSNUT 2007 to 2011-13). J Food Compos Anal 50, 30-35.

24. Food Standards Australia New Zealand (2008) AUSNUT 2007 brand file. Canberra: Food Standards Australia New Zealand.

25. McNaughton SA, Ball K, Crawford D, et al. (2008) An index of diet and eating patterns is a valid measure of diet quality in an Australian population. J Nutr 138, 86-93.

26. National Health and Medical Research Council (2003) Dietary guidelines for all Australians. http://www.nhmrc.gov.au/ publications/synopses/_files/n33.pdf (accessed July 2016).

27. National Health and Medical Research Council \& Ministry of Health (2006) Nutrient Reference Values for Australia and New Zealand Including Recommended Dietary Intakes. Canberra: National Health and Medical Research Council \& Ministry of Health.

28. National Health and Medical Research Council (2013) Educator Guide. Canberra: National Health and Medical Research Council. https://www.eatforhealth.gov.au/sites/default/files/files/ the_guidelines/n55b_eat_for_health_educators_guide.pdf

29. Diederichs C, Berger K \& Bartels DB (2011) The measurement of multiple chronic diseases - a systematic review on existing multimorbidity indices. J Gerontol A Biol Sci Med Sci 66, 301-311.

30. Gnjidic D, Hilmer SN, Blyth FM, et al. (2012) Polypharmacy cutoff and outcomes: five or more medicines were used to identify community-dwelling older men at risk of different adverse outcomes. J Clin Epidemiol 65, 989-995.

31. Hirani V, Naganathan V, Blyth F, et al. (2014) Multiple, but not traditional risk factors predict mortality in older people: the concord health and ageing in men project. Age 36, 9732.

32. National Heart Foundation of Australia (2016) Guideline for the diagnosis and management of hypertension in adults. http://heartfoundation.org.au/images/uploads/publications/PRO167_Hypertension-guideline-2016_WEB.pdf (accessed August 2016).

33. Bleicher K, Cumming RG, Naganathan V, et al. (2011) The role of fat and lean mass in bone loss in older men: Findings from the CHAMP study. Bone 49, 1299-1305.

34. Bannerman E, Miller MD, Daniels LA, et al. (2002) Anthropometric indices predict physical function and mobility in older Australians: the Australian Longitudinal Study of Ageing. Public Health Nutr 5, 655-662.

35. Visvanathan R, Haywood C, Piantadosi C, et al. (2011) Obesity and the older person, Position Statement no. 19. Sydney: Australian and New Zealand Society for Geriatric Medicine.

36. Berraho M, Nejjari C, Raherison C, et al. (2010) Body mass index, disability, and 13-year mortality in older French adults. J Aging Health 22, 68-83.

37. Sergi G, Perissinotto E, Pisent C, et al. (2005) An adequate threshold for body mass index to detect underweight condition in elderly persons: the Italian Longitudinal Study on Aging (ILSA). J Gerontol A Biol Sci Med Sci 60 , 866-871.

38. Kulminski AM, Arbeev KG, Kulminskaya IV, et al. (2008) Body mass index and nine-year mortality in disabled and nondisabled older U.S. individuals. J Am Geriatr Soc 56, 105-110. 
39. Winter JE, MacInnis RJ, Wattanapenpaiboon N, et al. (2014) BMI and all-cause mortality in older adults: a meta-analysis. Am J Clin Nutr 99, 875-890.

40. World Health Organization (2008) Waist Circumference and Waist-Hip Ratio: Report of a WHO Expert Consultation. Geneva: WHO.

41. Washburn RA, Smith KW, Jette AM, et al. (1993) The physical activity scale for the elderly (PASE): Development and evaluation. J Clin Epidemiol 46, 153-162.

42. Fried LP, Tangen CM, Walston J, et al. (2001) Frailty in older adults: evidence for a phenotype. J Gerontol 56A, M146-156.

43. Ware J Jr, Kosinski M \& Keller SD (1996) A 12-Item Short-Form Health Survey: construction of scales and preliminary tests of reliability and validity. Med Care 34, 220-233.

44. Burnham KP \& Anderson DR (2002) Model Selection and Multimodel Inference, 2nd ed. New York: Springer-Verlag.

45. R Core Team (2016) $R$ : A Language and Environment for Statistical Computing, 3.3.0 ed. ]. Vienna: R Foundation for Statistical Computing.

46. Gilbert PA \& Khokhar S (2008) Changing dietary habits of ethnic groups in Europe and implications for health. Nutr Rev 66, 203-215.

47. Darmon N \& Drewnowski A (2008) Does social class predict diet quality? Am J Clin Nutr 87, 1107-1117.

48. Gelman A \& Su Y-S (2015) arm: Data Analysis Using Regression and Multilevel/Hierarchical Models. https://CRAN.R-project.org/ package $=$ arm $($ accessed February 2017)

49. Bartoń K (2015) MuMIn: Multi-model inference. R package version 1.15.1. https://cran.r-project.org/web/packages/MuMIn/ index.html (accessed February 2017).

50. Burnham KP \& Anderson DR (2002) Model Selection and Multimodal Inference: A Practical Information-Theoretic Approach, 2nd ed. New York: Springer.

51. Nakagawa S \& Cuthill IC (2007) Effect size, confidence interval and statistical significance: a practical guide for biologists. Biol Rev Camb Philos Soc 82, 591-605.

52. Nakagawa S \& Schielzeth H (2013) A general and simple method for obtaining R2 from generalized linear mixedeffects models. Methods Ecol Evol 4, 133-142.

53. Venables WN \& Ripley BD (2002) Modern Applied Statistics with $S$, 4th ed. New York: Springer

54. Du S, Mroz TA, Zhai F, et al. (2004) Rapid income growth adversely affects diet quality in China - particularly for the poor!. Soc Sci Med 59, 1505-1515.

55. Thiele S, Mensink GBM \& Beitz R (2004) Determinants of diet quality. Public Health Nutr 7, 29-37.

56. Mullie P, Clarys P, Hulens M, et al. (2010) Dietary patterns and socioeconomic position. Eur J Clin Nutr 64, 231-238.

57. Aggarwal A, Monsivais P, Cook AJ, et al. (2011) Does diet cost mediate the relation between socioeconomic position and diet quality? Eur J Clin Nutr 65, 1059-1066.

58. Andrieu E, Darmon N \& Drewnowski A (2005) Low-cost diets: more energy, fewer nutrients. Eur J Clin Nutr $\mathbf{6 0}$, 434-436.

59. Agarwal K, Chadha R \& Tandon N (2015) Association of cost and quality of diets with risk of non-communicable diseases: a review. Am J Public Health Res 3, 167-173.

60. Drewnowski A (2004) Obesity and the food environment: dietary energy density and diet costs. Am J Prev Med 27, 154-162.

61. Sergi G, Bano G, Pizzato S, et al. (2016) Taste loss in the elderly: possible implications for dietary habits. Crit Rev Food Sci Nutr 57, 3684-3689.
62. Dean M, Raats MM, Grunert KG, et al. (2009) Factors influencing eating a varied diet in old age. Public Health Nutr 12, 2421-2427.

63. Maindal HT, Toft U, Lauritzen T, et al. (2013) Three-year effects on dietary quality of health education: a randomized controlled trial of people with screen-detected dysglycaemia (The ADDITION study, Denmark). Eur J Public Health 23, 393-398.

64. Morabia A \& Wynder EL (1990) Dietary habits of smokers, people who never smoked, and exsmokers. Am J Clin Nutr 52, 933-937.

65. Haibach JP, Homish GG \& Giovino GA (2013) A longitudinal evaluation of fruit and vegetable consumption and cigarette smoking. Nicotine Tob Res 15, 355-363.

66. Dallongeville J, Marécaux N, Fruchart J-C, et al. (1998) Cigarette smoking is associated with unhealthy patterns of nutrient intake: a meta-analysis. J Nutr 128, 1450-1457.

67. Australian Bureau of Statistics (2016) Australian Health Survey: Consumption of Food Groups from the Australian Dietary Guidelines, 2011-12. Canberra: Australian Bureau of Statistics.

68. Brooks RC, Simpson SJ \& Raubenheimer D (2010) The price of protein: combining evolutionary and economic analysis to understand excessive energy consumption. Obes Rev 11, 887-894.

69. Vergeer M, Holleboom AG, Kastelein JJP, et al. (2010) The HDL hypothesis: does high-density lipoprotein protect from atherosclerosis? J Lipid Res 51, 2058-2073.

70. Hung H-C, Joshipura KJ, Jiang R, et al. (2004) Fruit and vegetable intake and risk of major chronic disease. $J$ Natl Cancer Inst 96, 1577-1584.

71. Bazzano LA, He J, Ogden LG, et al. (2002) Fruit and vegetable intake and risk of cardiovascular disease in US adults: the first National Health and Nutrition Examination Survey Epidemiologic Follow-up Study. Am J Clin Nutr 76, 93-99.

72. Seal CJ \& Brownlee IA (2015) Whole-grain foods and chronic disease: evidence from epidemiological and intervention studies. Proc Nutr Soc 74, 313-319.

73. National Health and Medical Research Council (2013) Australian Dietary Guideline. Canberra: National Health and Medical Research Council.

74. Visser M, De Groot LCPGM, Deurenberg P, et al. (1995) Validation of dietary history method in a group of elderly women using measurements of total energy expenditure. $\mathrm{BrJ}$ Nutr 74, 775-785.

75. McNeill G, Winter J \& Jia X (2009) Diet and cognitive function in later life: a challenge for nutrition epidemiology. Eur J Clin Nutr 63, Suppl. 1, S33-S37.

76. Van Staveren W, Burema J, Livingstone M, et al. (1996) Evaluation of the dietary history method used in the SENECA Study. Eur J Clin Nutr 50, S47-S55.

77. Margetts B \& Nelson M (1997) Design Concepts in Nutritional Epidemiology, 2nd ed. New York, NY: Oxford University Press.

78. Shahar S, Earland J \& Abdulrahman S (2000) Validation of a dietary history questionnaire against a 7-D weighed record for estimating nutrient intake among rural elderly Malays. Malays J Nutr 6, 33-44.

79. Willett W (1998) Nutritional Epidemiology. New York, NY: Oxford University Press.

80. Hebert JR, Clemow L, Pbert L, et al. (1995) Social desirability bias in dietary self-report may compromise the validity of dietary intake measures. Int J Epidemiol 24, 389-398. 